University of California, Hastings College of the Law UC Hastings Scholarship Repository

Faculty Scholarship

2015

\title{
Vaccines, School Mandates, and California's Right to Education
}

Dorit Rubenstein Reiss

UC Hastings College of the Law, reissd@uchastings.edu

Follow this and additional works at: http://repository.uchastings.edu/faculty_scholarship

\section{Recommended Citation}

Dorit Rubenstein Reiss, Vaccines, School Mandates, and California's Right to Education, 63 UCLA L. Rev. Disc. 98 (2015). Available at: http://repository.uchastings.edu/faculty_scholarship/1483

This Article is brought to you for free and open access by UC Hastings Scholarship Repository. It has been accepted for inclusion in Faculty Scholarship by an authorized administrator of UC Hastings Scholarship Repository. 
Vaccines, School Mandates, and California's Right to Education

Dorit Rubinstein Reiss

\begin{abstract}
California recently enacted Senate Bill 277, which abolishes the personal beliefs exemption to school immunization requirements. One possible challenge to the law's constitutionality is that it impermissibly limits the right to education. This Essay rebuts such a position. California's jurisprudence regarding access to education applies to protected categories; it does not limit the ability of the state to impose health and safety regulations such as immunization requirements. Moreover, the requirement would withstand even strict scrutiny, if applied, because disease prevention in the school context is a compelling interest and there is no alternative that is as effective. Finally, the law actually protects the right of access to education for those whose parents do not have the luxury of choice, such as immune-compromised children, while still reasonably preserving parental choice overall.
\end{abstract}

\title{
AUTHOR
}

Professor of Law, UC Hastings College of the Law. Acknowledgements: I am grateful to Megan Banta, David Roth, Leah Russin, Stephen Sugarman, and Narad Trabant for their insightful and very, very helpful comments on previous drafts. I am also grateful to Kiran Sidhu for her excellent research work. All errors are, of course, my own. 


\section{TABLE OF CONTENTS}

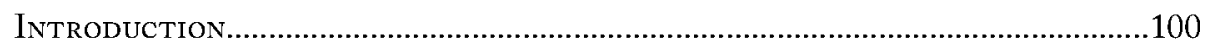

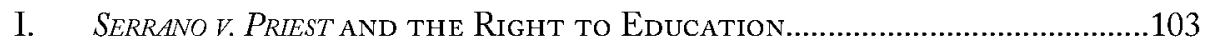

A. The Three Serrano Cases Protect Access to Education for Suspect Categories ................................................................... 103

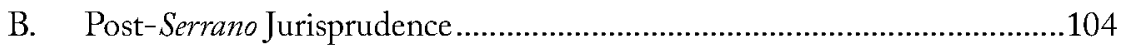

II. SB 277 Withstands the Compelling Interest and Least Restrictive Means Requirements

III. Whose Right to Access? SB 277 Protects the Right to Access of Those Who Cannot Be Vaccinated ......................................................114

III. SB 277 Does Not Remove Choice, Though It Limits It.........................116

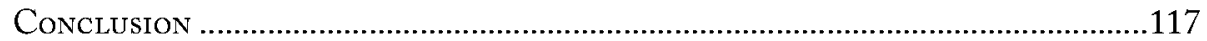




\section{INTRODUCTION}

On June 30, 2015, California governor Jerry Brown signed into law Senate Bill 277 (SB 277), ${ }^{1}$ which abolished the state's personal belief exemption (PBE) to school immunization requirements. Like all states, California requires that children attending school be immunized. California's statute applies to both public and private daycares and schools and as of July 2015 requires immunization against ten preventable, dangerous diseases. ${ }^{2}$ Before SB 277 was passed, the PBE allowed parents to send their children to school despite having declined some or all of the required vaccines. Initially, all that was required was signing a form expressing an objection to vaccination based on undefined personal beliefs.

PBE rates have gone up dramatically since 1994. In 1994, schools on average had 0.6 percent of kindergarten students claiming PBE; by 2009, the number was 2.3 percent. $^{3}$ By the 2013-2014 school year, schools, on average, had 3.15 percent of kindergarten students claiming PBE. ${ }^{4}$ While these percentages may seem low, they are not evenly distributed: Some communities have much higher rates, and a recent research paper demonstrated that those communities were most vulnerable to outbreaks. ${ }^{5}$

1. S.B. 277, 2015-16 Leg., Reg. Sess. (Cal. 2015), ch. 35, 2015 Cal. Stat. 91, http://www.leginfo.ca.gov/pub/15-16/bill/sen/sb_0251-0300/sb_277_bill_20150630_chaptered.pdf; see also Letter from Governor Edmund G. Brown, Jr., Gov'r of Calif., to the Members of the California State Senate (June 30,2015), http://gov.ca.gov/docs/SB_277_Signing_Message.pdf.

2. CAL. HEALTH \&SAFETY CODE $\$ 120335$ (b) (West 2012).

3. Jennifer L. Richards et al., Nonmedical Exemptions to Immunization Requirements in California: $A$ 16-Year Longitudinal Analysis of Trends and Associated Community Factors, 31 VACCINE 3009, 3011 (2013). This represents an average increase of 8.8 percent each year.

4. CAL. DEP'T HeALTH, IMMUNIZATION BRACH, 2014-2015 KindergarteN IMMUNIZATION ASSESSMENT RESULTS (Feb. 2015), https:/www.cdph.ca.gov/programs/ immunize/Documents/2014-15\%20CA\%20Kindergarten\%20Immunization\%20Assessment.pdf. Between the 2013-2014 school year and the 2014-2015 school year, however, that number declined to 2.54 percent.

5. Maimuna S. Majumder et al., Substandard Vaccination Compliance and the 2015 Measles Outbreak, 169 JAMA PEDIATRICS 494, 494 (2015). 
As of January 2014, following a bill passed in 2012, an informational requirement was imposed on the then-available exemption. Assembly Bill $2109^{6}$ required parents to obtain the signature of a healthcare provider - broadly defined to include school nurses, certain naturopaths, and others, in addition to doctors of osteopathic medicine (DOs) and medical doctors (MDs) - attesting that the parents were given information about the risks of vaccine-preventable diseases before making the decision not to vaccinate their child. ${ }^{7}$ This essentially constituted a requirement of informed refusal. ${ }^{8}$ In the year following $\mathrm{AB} 2109$, the percentage of PBEs in kindergarten decreased by 19 percent (from 3.15 percent to 2.54 percent), but the overall immunization rates went up only slightly. ${ }^{9}$ During the hearings, Senator Richard Pan explained that experience from Washington State suggests that while their informed refusal law initially decreased the rate of PBE, that trend stalled. In other words, informed refusal laws do not sufficiently increase vaccination rates. ${ }^{10}$

Under SB 277, children will only be able to attend school or daycare, public or private, if they either receive the immunizations required by law or obtain a medical exemption from the requirement from a licensed physician-meaning only MDs and DOs. ${ }^{11}$ Children may also be conditionally accepted into a school or daycare program if they are in the process of completing a series of vaccinations. In other words, if parents wish to leave their children unvaccinated, absent

6. A.B. 2109, 2011-12 Leg., Reg. Sess. (Cal. 2012), ch. 821, 2012 Cal. Stat. 94 (codified as amended at CAL. HEALTH \& SAFETY CODE $\$ 120365$ (West 2012)), http://www.leginfo.ca.gov/pub/1112/bill/asm/ab_2101-2150/ab_2109 bill_20120930_chaptered.pdf.

7. CAL. HEALTH \& SAFETY CODE $\$ \$ 120365(\mathrm{~b}),(\mathrm{f})$.

8. See Ross D. Silverman, No More Kidding Around: Restructuring Non-Medical Childhood Immunization Exemptions to Ensure Public Health Protection, 12 ANNALS HEALTH L. 277, 294 (2003) ("[A]ny applicant wishing to apply for an exemption should be required to undergo an 'informed refusal' process. Prior to receiving an exemption, applicants would meet with a health professional (e.g. public health officer, school nurse, or primary care provider) to discuss the relative risks and benefits of immunization and exemption. This interaction would need to be memorialized on a standardized form.").

9. CAL. DEP'T HEALTH, supra note 4.

10. See WASH. STATE DEP'T OF HEALTH, WASHINGTON STATE SCHOOL IMMUNIZATION DATA: SCHOOL YEAR 2014-2015 (Apr. 2015), http://www.doh.wa.gov/Portals/1/Documents/Pubs/348 246-SY2014-15-ImmunizationGraphs.pdf.

11. Section 120370 determines the requirements for a medical exemption, which require that a physician write a statement "to the effect that the physical condition of the child is such, or medical circumstances relating to the child are such, that immunization is not considered safe, indicating the specific nature and probable duration of the medical condition or circumstances that contraindicate immunization." CAL. HEALTH \& SAFETY CODE § 120370 (West 2012). SB 277 added a requirement that the doctor consider medical history, though it's undear what effect that will have, if any. The provision seems to give doctors broad discretion to grant medical exemptions, and there is currently no real path to oversee that discretion. 
an acknowledged medical reason to do so, they cannot send them to school or daycare. They will, however, have a variety of other options available. These options include homeschooling their children on their own or in collaboration with a few other families, or participating in certain independent study programs offered by public schools.

Opponents of the bill and critics of vaccines fought (and continue to fight) vigorously against $\mathrm{SB} 277$, sometimes with disturbing tactics. ${ }^{12}$ One recurrent theme was that the bill is unconstitutional. This Essay does not address the claim that SB 277 violates the federal constitution, as this subject has been thoroughly discussed elsewhere, and our jurisprudence is consistent in upholding school immunization requirements with no nonmedical exemptions. ${ }^{13}$ Instead, I focus on the claim that the bill is unconstitutional under state law because it violates a child's right to access public education, which has been acknowledged by the California Supreme Court to be a fundamental societal interest. ${ }^{14}$ Part I explains why Serrano v. Priest ${ }^{15}$ and subsequent cases addressing Serrano's holding-in relation both to equal protection and to access to education-do not support the application of strict scrutiny to SB 277. In reality, Serrano has never been used to limit the state's ability to ensure the health and safety of children in schools; these are a precondition to education, and our jurisprudence treats them as such. Attempting to use Serrano to attack a health and safety requirement goes against both the letter of the ruling and its spirit.

Part II addresses the compelling interest test, showing that even if strict scrutiny were applied, SB 277 would meet the standard. Part III examines whether a right of unvaccinated children to access schools and daycare services would create an increased risk of outbreaks that puts others at risk, including those who cannot be vaccinated. This in turn could be construed as limiting medically exempt children's rightful access to education, by requiring such naturally vulnerable popula-

12. See Anna Merlan, Meet the New, Dangerous Fringe of the Anti-Vaccination Movement, JEZEBEL (June 29, 2015, 12:50 PM), http://jezebel.com/meet-the-new-dangerous-fringeof-the-anti-vaccination-1713438567 [http://perma.cc/Z26A-WGEM]; Orac, Revealing the True Face of the Antivacine Movement, RESPECTFUL INSOLENCE (Jun. 30, 2015), http://scienceblogs.com/insolence/2015/06/30/revealing-the-true-face-of-the-antivaccinemovement [http://perma.co/WQ8M-L8TQ].

13. See Dorit Rubinstein Reiss \& Lois A. Weithorn, Responding to the Cbildbood Vaccination Crisis: Legal Frameworks and Tools in the Context of Parental Vaccine Refusal, 63 BUFF. L. REV. (forthcoming Aug. 2015), http://ssm.com/abstract=2574001; see generally Dorit Rubinstein Reiss, Thou Shalt Not Take the Name of the Lord Thy God in Vain: Use and Abuse of Religious Exemptions From School Immunization Requirements, 65 HASTINGS L.J. 1551 (2014).

14. Serrano v. Priest (Serrano D), 487 P.2d 1241, 1255 (Cal. 1971).

15. Id. 
tions to avoid areas with low vaccination rates. Between families that have a choice to vaccinate and those that do not, those with no choice have the stronger claim to access. Finally, Part IV points out that if homeschooling is a legitimate educational option in California, then parents choosing to reject school requirements are not denied a choice. Rather, they are choosing between following the health and safety rules the state has adopted and exercising their right to reject those rules. From every angle examined, SB 277 does not violate California's Constitution as interpreted in Serrano.

\section{SERRANOV.PRIESTANDTHE RIGHTTO EDUCATION}

\section{A. The Three Serrano Cases Protect Access to Education for Suspect Categories}

In a set of cases that were heard by California's Supreme Court three times, plaintiffs challenged the financing of California's school system by claiming that discrimination based on wealth violated equal protection. In the initial case, the Supreme Court overturned the trial court's grant of a motion to dismiss, ruling that the state's financing system did, indeed, violate the Fourteenth Amendment by discriminating based on wealth. The court emphasized that in instances of wealth-based discrimination, courts traditionally evaluate the existence of a fundamental interest, explaining that "[u]ntil the present time wealth classifications have been invalidated only in conjunction with a limited number of fundamental interests - rights of defendants in criminal cases ... and voting rights." ${ }^{16}$ The court found education to be such a fundamental interest. ${ }^{17}$

The court went on to discuss the "indispensable role which education plays in the modern industrial state." ${ }^{8}$ The Serrano court highlighted the importance of education, both to the individual and her participation in modern society and to society itself. ${ }^{19}$ The court based its analysis, to a large extent, on a thorough legal review discussing the importance of education in modern society and offering

16. Serrano I, 487 P.2d 1241, 1255 (citations omitted). This point was reaffirmed in Serrano v. Priest (Serrano II), 557 P.2d 929, 948 (Cal. 1976) (explaining that the school financing system "involved both a 'suspect classification' (because the discrimination in question was made on the basis of wealth) and affected a 'fundamental interest' (education)").

17. Serrano I, 487 P.2d 1241, 1255.

18. Id. at 1256 .

19. Id. at $1256-59$ (citations omitted). 
compelling arguments in support of acknowledging education as a fundamental interest. ${ }^{20}$

Serrano justifiably stands for the importance of education under California's constitutional law. But it is important to remember that the decision was made in the context of examining whether wealth was a suspect classification that justified applying strict scrutiny to the state's school financing system. In other words, the emphasis on education was raised not in the abstract-not to provide for strict scrutiny every time the state attempts to regulate schools - but to prevent the state from limiting access to education based on a suspect classification.

\section{B. Post-Serrano Jurisprudence}

What does subsequent jurisprudence teach us about Serrano? There are two ways in which it clearly does not support the argument that SB 277 is unconstitutional under Serrano. First, children intentionally unvaccinated do not constitute a suspect classification that may be entitled to strict scrutiny in the context of limiting access to education. Second, if anything, post-Serrano cases have upheld the state's ability to regulate the school environment for safety. They certainly do not, in any way, undermine it, as described below.

Although California's jurisprudence recognizes a broader set of classifications as deserving of special protection than does federal constitutional law - for example, despite the holding of San Antonio Independent School District v. Rodriguez ${ }^{21}$ at the federal level, wealth can still be a suspect classification in some contexts, as clarified in the second Serrano case ${ }^{22}$ — not every distinction made by the state deserves application of strict scrutiny. That is not surprising. Most laws make some distinctions - including laws that may affect fundamental interests like education. For example, education laws traditionally distinguish by age. Fundamental interests are not absolute, and not every classification or distinction applied to them is problematic. As explained in Romerv. Evans:

$[T]$ he equal protection of the laws must coexist with the practical necessity that most legislation classifies for one purpose or another, with resulting disadvantage to various groups or persons. ${ }^{23}$

20. See id. (citing John E. Coons et al, Educational Opportunity: A Workable Constitutional Test for State Financial Structures, 57 CAL. L. REV. 305, 388 (1969)).

21. 411 U.S. 1, 19-20 (1973).

22. Serrano II, 557 P.2d 929, 951-52 (Cal. 1976).

23. Romerv. Evans, 517 U.S. 620, 631 (1996). 
While Romer is a federal decision, the point stands: legislation classifies, and not all classifications are equally problematic. Here, most post-Serrano cases examined suspect classifications like race or wealth. ${ }^{24}$ Even the closest cases do not support the claim of SB 277 opponents that Serrano means that SB 277 should be reviewed for constitutional deficiencies under a strict scrutiny standard. In King v. McMabon, ${ }^{25}$ California's First District Court of Appeal, referring to Darces v. Woods, ${ }^{26}$ highlighted that

Darces, although advocating a more flexible approach to equal protection analysis, nevertheless took pains to connect the classification with more traditional indicia of a suspect class-national origin and ancestry. According to the court:

We have thus far emphasized the reason appellant's children constitute a discrete minority - their inability to control their parents' conduct. Equally crucial to our holding is the fact that appellant's citizen children are classified on the basis of an immutable trait- they cannot forsake their birth into an undocumented family. ${ }^{27}$

Both King and Darces considered access to the right to receive state financial benefits. In Darces, children were denied welfare benefits because their undocumented siblings were living in the same house. ${ }^{28}$ The court applied strict scrutiny to invalidate this state action. ${ }^{29} \mathrm{SB} 277$ opponents argue that the justification for strict scrutiny cited by the Darces court - that the children in question did not ask to be deprived of these benefits, but were suffering because of a choice made by their parents - applies with equal force to children who did not ask to be deprived of vaccinations and, by application of SB 277, an education.

Yet the King court rebuts this argument, by properly focusing the inquiry on whether the basis of the discrimination was an immutable characteristic. ${ }^{30}$ In King, plaintiffs argued that the decision whether to place children with relatives - as opposed to placing them with unrelated families- should be subject to strict scruti-

24. See Crawford v. Bd. of Educ., 551 P.2d 28 (Cal. 1976). Other cases, like Butt v. State, 842 P.2d $1240,1257-58$ (Cal. 1992), focused on not providing minimal services to a large group of students, which is a different issue.

25. King v. McMahon, 186 Cal. App. $3 d 648$ (Cal. Ct. App. 1986).

26. Darces v. Woods, 679 P.2d 458 (Cal. 1984) (en banc).

27. King, 186 Cal. App. 3d at 657.

28. Darces, 679 P.2d at 460.

29. Id. at 469.

30. King, 186 Cal. App. 3d at 658. 
ny. ${ }^{31}$ The court rejected the application of strict scrutiny, reasoning that foster care placement is not an immutable trait. As the excerpt above highlights, King emphasized that the court in Darces had applied strict scrutiny not only because children have no control over the choices of their parents - the argument cited by vaccine opponents - but also because discrimination was occurring on the basis of immutable characteristics. ${ }^{32}$ Immutable characteristics were not present in the facts of the King case. ${ }^{33}$ Similarly, the parental choice not to vaccinate has nothing to do with any immutable trait: $\mathrm{It}$ is a voluntary choice by the parents that is unconnected to anything resembling national origin or ancestry.

Even if the opposition to vaccine is based on a religious belief, that would not be an immutable characteristic: Both federal jurisprudence and state law allow limiting potentially harmful conduct even if religiously motivated. On the federal level, under Employment Division v. Smith, ${ }^{34}$ a neutral law of general application can apply to those with religious objections. On both the federal ${ }^{35}$ and at the state level ${ }^{36}$ statutes criminalizing, for example, female circumcision are not problematic, even if the act is religiously motivated. To take a less extreme example, Prince v. Massachusetts upheld child labor law against a challenge based on Jehovah Witnesses' sincere belief in the importance of having children proselytize, because conduct can be regulated, even if religiously motivated. ${ }^{37}$ Religious identity may be immutable, but behavior — especially harmful behavior — is not, even when it is motivated by religion.

Refusal to vaccinate is a choice that imposes risks on others, because unvaccinated children are themselves at much higher risk of contracting preventable diseases than vaccinated children. ${ }^{38}$ Moreover, communities with lower rates of immunization are at much higher risk of outbreaks. ${ }^{39}$ Acting in ways that create

31. Id. at $651-52$.

32. In Darces, the court noted that the equal protection clause had been violated because "innocent children cannot be explicitly disadvantaged on the basis of their status of birth." Darces, 679 P.2d at 471.

33. King, $186 \mathrm{Cal}$. App. 3d at 658.

34. Emp't Div. v. Smith, 494 U.S. 872, 888-90 (1990)

35. 18 U.S.C. $\$ 116(2012)$

36. E.g. GA. CODE ANN. §16-5-27 (2013).

37. Prince v. Massachusetts, 321 U.S. 158, 170 (1944).

38. See Daniel R. Feikin et al., Individual and Community Risks of Measles and Pertussis Associated With Personal Exemptions to Immunization, 284 JAMA 3145, 3147-49 (2000); Jason M. Glanz et al., Parental Refusal of Pertussis Vaccination Is Associated With an Increased Risk of Pertussis Infection in Children, 123 PEDIATRICS 1446, 1449-50 (2009).

39. Aamer Imdad et al., Religious Exemptions for Immunization and Risk of Pertussis in New York State, 2000-2011, 132 PEDIATRICS 37, 38 (2013); Saad B. Omer et al., Geographic Clustering of 
a risk to others is not an immutable characteristic, and regulation that treats people behaving in a manner that creates risk to others differently from those who do not create such risk does not violate equal protection. This type of distinction is not a suspect classification and thus does not trigger strict scrutiny.

Behavior that imposes risks on others can and should be regulated. For example, the state can and does regulate one's ability to drink and drive; while you are free to drink, the state can penalize you if you drive while under the influence, because that behavior creates a risk. ${ }^{40}$ You have the right to refuse treatment for tuberculosis, but the state may quarantine you as a consequence of the infection risk you pose to others- even though no one contests the fact that freedom from restraint is a fundamental interest. ${ }^{41}$

In this context, parents who choose not to vaccinate are more like those who choose to drink and drive than they are those who are members of an ethnic group. They have no more claim of discrimination than does the Association Against Discriminating on the Basis of Alcohol Consumption (ADOBAC). ${ }^{42}$

If the parent wanted to send the child to school clearly ill, there is no argument that the school could prevent that, and the state can regulate to protect other children from the illness. This is not prevented by Serrano. Acting preemptively to prevent an attending child from falling ill-by requiring vaccination, which reduces the chances of illness by up to 97 percent (for two doses of $\mathrm{MMR}^{43}$ ) - is likewise permissible.

We could even push the discussion further and highlight that Serrano generally does not cover behavioral choices. If parents wanted to send a child to school naked, the school could prevent that, even if there is no risk to others, and Serrano would not apply. Similarly, Serrano does not apply when parents want to send the children to school unvaccinated.

Nonmedical Exemptions to School Immunization Requirements and Associations With Geographic Clustering of Pertussis, 168 AM. J. EPIDEMIOLOGY 1389, 1394-95 (2008).

40. See Charles E. Phelps, Control of Alcohol-Involved Driving Through Impersonal Prevention, 14 ALCOHOL HEALTH \& RES. WORLD 52, 53 (1990).

41. City of Newark v. J.S., 652 A.2d 265, 274 (Super. Ct. N.J. 1993). For a discussion of the longstanding interest the state has in protecting the well-being of children, even in light of competing interests, see Reiss \& Weithorn, supra note 13 ("[P]olice power concerns are substantially broader in the case of children. Not only is the state concerned with containing public health risks . .., but it is even more fundamentally concerned with promoting the overall healthy development and socialization of those who will become tomorrow's adults.").

42. A purely fictional association.

43. Measles, CTR. FOR DiSEASE CONTROL \& PREvEnTION, http://www.cdc.gov/ measles/vaccination.html (last visited Sept. 27, 2015) [http://perma.cc/DT9N-L93D]. 
While a minority of parents may have religious reasons to reject vaccination (the PBE covered religious exemptions as well), and religion is a suspect classification, the evidence is that most people who do not vaccinate do not base the decision on religious reasons. ${ }^{44} \mathrm{~A}$ minority of those who reject vaccines may do so for religious reasons, but SB 277 does not target that minority; it is a neutral law of general applicability, and therefore constitutional under our federal First Amendment jurisprudence. ${ }^{45}$

Existing jurisprudence thus teaches us that Serrano would not apply to the category of differing vaccination status, if there were such a category, under an equal protection heading. Nor would it prevent the state from imposing school immunization requirements - with no nonmedical exemption required.

Although education is a fundamental interest, it is not, and has never been, an unregulated sphere. California has an entire education code and regulates schools in many aspects. Post-Serrano cases naturally brought challenges against some of those regulations, testing the boundaries of the doctrine. I have found no case in which Serrano led to the striking down of a health and safety regulation. Regulations that further access to education and prevent disruption of education are usually upheld.

Most notably, in Montalvo v. Madera ${ }^{46}$ a junior high school student attacked the validity of a school regulation limiting the length of his hair. The school justified the regulation as necessary to prevent disruption of education. ${ }^{47}$ The court upheld the restriction, deferring to the school authorities' judgment. ${ }^{48}$ Note that this regulation focuses on a limitation that is not connected to preservation of life or the prevention of immediate severe harm. Furthermore, it was not a state law enjoying the aura of legitimacy that being passed by a democratically elected legislature confers. Nonetheless, the regulation was upheld, and Serrano not applied, because school and state authorities may regulate schools to promote orderly conduct, health, and safety. This is exactly what school immunization requirements do.

The next relevant case ended in a settlement and was never published. One site explains it as follows:

44. Reiss, supra note 13 , at $1570-88$.

45. Id. at 1562-63; Reiss \& Weithorn, supra note 13, at 7-8. Note that California does not have a Religious Freedom Restoration Act, which may raise additional questions on this score.

46. Montalvo v. Madera Unified Sch. Dist. Bd. of Educ., 21 Cal. App. 3d 323, 337 (Cal. Ct. App. 1971).

47. Id. at 327 .

48. Id. at $330-31$. 
In 1999, several California organizations filed a school funding case, Williams v. State, in state superior court on behalf of a class of students attending substandard schools. The complaint cited inadequate, unsafe, and unhealthy facilities, a shortage of qualified teachers, missing libraries, a lack of instructional materials, and overcrowded schools that resulted in a staggered and shortened school year (together known as Concept 6). The state filed cross-claims against 18 school districts, but in 2000 plaintiffs won a motion to sever and stay proceedings on the cross-claims.

The court granted class certification in 2001, the Williams plaintiffs released their experts' reports in 2002, and the trial was scheduled to begin in 2004. Instead, in August 2004, the parties announced a settlement-later approved by the court - to: (1) provide $\$ 800$ million over the next several years for school repairs; (2) create a School Facilities Needs Assessment program; (3) create standards for instructional materials and facilities; (4) require a complaint process for inadequate instructional materials, teacher vacancies, and emergency facilities problems; (5) intervene in schools ranked in the bottom $30 \%$ under the 2003 Academic Performance Index if instructional materials and facilities standards are not met; (6) streamline California credentialing for out-of-state credentialed teachers; (7) allocate about $\$ 140$ million for instructional materials in 2004-2005; and several other provisions. ${ }^{49}$

In other words, these plaintiffs used Serrano to attack schools that were, inter alia, "unsafe, and unhealthy"-underscoring the importance of health and safety as a precondition to education. ${ }^{50}$

Unsurprisingly, disease outbreaks also undermine education. During an outbreak, students who are not vaccinated (including children who cannot be vaccinated for legitimate medical reasons) are kept out of school, both for their own safety and to contain the outbreak. ${ }^{51}$ Those students' educations are clearly interrupted. A classroom in which a large number of students are absent will not be able to conduct business as usual, especially as children come back and need to

49. Historical Background: Serrano v. Priest, NAT'L EdUC. ACcess NeTwork, http://www.schoolfunding.info/states/ca/lit_ca.php3 (last updated Mar. 2011) [http://perma.cc/AF28-9UGC].

50. See also Jeannie Oakes \& Martin Lipton, "Schools That Shock the Conscience": Williams v. California and the Struggle for Education on Equal Terms Fifty Years After Brown, 11 ASIAN L.J. 234, 236-37 (2004).

51. See, e.g., Liz Szabo, Measles Outbreak Raises Question of Vaccine Exemptions, USA TODAY (Jan. 23, 2015, 8:45 AM), http://www.usatoday.com/story/news/2015/01/21/disneyland-measlesschools-outbreak/22106151 [http://perma.cc/YY64-YJNL]. 
catch up, often at different times, requiring teacher attention and focus. Outbreaks also consume valuable resources, especially limited time from school administrators and nurses, who need to identify and track the students at risk. Because resources are finite, that time has to come from elsewhere, at the cost of other activities. If teachers fall ill, that can also disrupt education. Teachers, too, deserve better than to be sick and potentially harmed by preventable illnesses. Of course, the sick students themselves miss school. In addition, a child may die from such a disease, or be disabled in a way that prevents or limits their subsequent education. In other words, just as disease outbreaks impose costs and harms on public health officials and society ${ }^{52}$ and divert resources from other important objectives, ${ }^{53}$ they also impose costs on schools and disrupt education.

As mentioned above, vaccination refusal increases the risk of outbreaks. There is abundant evidence that easier-to-obtain exemptions lead to lower vaccination rates ${ }^{54}$ and that having fewer barriers to obtaining exemptions is connected with higher rates of preventable disease. ${ }^{55}$ State exemption policies can directly affect the degree to which schools are protected against outbreaks, ${ }^{56}$ and outbreaks directly impact education. The suggestion that Serrano limits the ability of the state to impose regulations aimed at preventing outbreaks goes against its spirit and goal, actually undermining the right to education rather than promoting it.

Although there are no California cases on point, a New York case examined the tension between the right to education and a requirement for vaccination. In deciding In re Viemeister, ${ }^{57}$ New York's Court of Appeals - which, despite the name, is its highest court - examined whether an immunization requirement (at

52. See generally Charlotte A. Moser et al., Funding the Costs of Disease Outbreaks Caused by Non Vaccination, 43 J.L. MED. \&ETHICS (forthcoming 2015), http://ssm.com/abstract=2445610.

53. Id.

54. See Nina R. Blank et al, Exempting Schoolchildren From Immunizations: States With Ferw Barriers Had Highest Rates of Nonmedical Exemptions, 32 HEALTH AFF. 1282, 1282 (July 2013); Walter A. Orenstein \& Alan R. Hinman, The Immunization System in the United States-the Role of School Immunization Larus, 17 VACCINE S19, S20 (1999).

55. Saad B. Omer et al., Nonmedical Exemptions to School Immunization Requirements: Secular Trends and Association of State Policies With Pertussis Incidence, 296 JAMA 1757, 1762 (2006).

56. See also W. David Bradford \& Anne Mandich, Some State Vaccination Laws Contribute to Greater Exemption Rates and Disease Outbreaks in the United States, 34 HEALTH AFF. 1383, 1383 (Aug. 2015).

57. In $r$ V Viemeister, 72 N.E. 97,98 (N.Y. 1904). For another view that attacking SB 277 based on the right to education is unlikely to succeed, see Michelle M. Mello et al., Shifting Vaccination PoliticsThe End of Personal-Belief Exemptions in California, 373 NEw ENG. J. MED. 785 (Jul. 27, 2015), http://www.nejm.org/doi/pdf/10.1056/NEJMp1508701. 
a time, moreover, when there was no current outbreak) violated the state's explicit constitutional right to an education. The court concluded that:

The right to attend the public schools of the state is necessarily subject to some restrictions and limitations in the interest of the public health. ... If vaccination strongly tends to prevent the transmission or spread of this disease [smallpox], it logically follows that children may be refused admission to the public schools until they have been vaccinated. ${ }^{58}$

In other words, if vaccination prevents and minimizes the risk of transmission of harmful diseases, it may be required as a condition of school attendance, because of the need to protect the health of other students. ${ }^{59}$

The closest California case opponents could use would be Phipps v. Saddleback Valley Unified School District. ${ }^{60}$ In this case, the court overturned a requirement that a child with acquired immune deficiency syndrome (AIDS) be homeschooled. But the grounds for the court's decision to uphold a permanent injunction against the school district ${ }^{61}$ did not involve a constitutional argument for access under Serrano. Rather, the decision rested on the lack of evidence for a risk of infection and examined the use of administrative discretion. It cannot stand for the proposition that risk of infection does not justify limiting access. In Phipps, no such risk was found. Finally, although not discussed explicitly in the decision, Phipps would be easily distinguished because having AIDS is, sadly, still an immutable characteristic, while being unvaccinated without medical justification is not. Parents of a child infected with AIDS cannot change their child's condition, as much as they would like to, since AIDS currently remains incurable. Just as race or ethnicity, a child and her family have no choice in the matter.

\section{SB277WITHSTANDSTHE COMPELLING INTEREST AND LEAST RESTRICTIVEMEANS REQUIREMENTS}

Even if one assumes-and, as explained above, this would probably be erroneous - that SB 277 is subject to strict scrutiny, there is reason to think that it would meet that standard. The federal constitution almost certainly does not require holding school immunization laws to this standard, not even in relation to religious exemptions (The California Constitution's position on

\footnotetext{
In re Viemeister, 72 N.E. at 98.

And unlike SB 277, the New York law was upheld even without a medical exemption.

204 Cal. App. 3d 1110 (Cal. Ct. App. 1988).

"[S]ubject to appropriate medical exam at least every six months." Id. at 1116.
} 
this has not yet been addressed by the courts). ${ }^{62}$ In Workman v. Mingo County Board of Education, the Fourth Circuit Court of Appeals decided that school immunization requirements with no nonmedical exemptions would survive even strict scrutiny, because protecting against infectious disease is a compelling interest. ${ }^{63}$

This decision seems to be eminently justified. All the diseases we vaccinate against carry substantial risks, which far outweigh vaccines' small risks. ${ }^{64}$ Schools are areas of high transmission, ${ }^{65}$ and again, communities with low vaccination rates are at much higher risk of disease. ${ }^{66}$ Minimizing the risks of these dangerous diseases to children in school and to those they may infect (for example, newborns or the elderly) is potentially a matter of life and death. ${ }^{67}$ There are few interests stronger than that.

SB 277 creates a situation in which there is no nonmedical exemption from school immunization requirements. Is this a narrowly tailored solution? The vast majority of states offer a religious exemption, and many a PBE or "philosophical" exemption, alongside the requirement to vaccinate. Furthermore, a law with no "out," or a law without a nonmedical exemption, carries its own risks, as I have addressed elsewhere:

Absent an exemption, parents may resort to extreme measures. They may decide that the only way to avoid harming their children is to falsify records. With exemptions, unvaccinated children are known, and schools typically exclude them if there is an outbreak-something for which state laws provide. This exclusion in the face of an outbreak would not be possible if unvaccinated students are not accurately identified. If no personal belief exemptions were allowed, parents may vac-

62. See Reiss \&Weithorn, supra note 13, at 43.

63. Workman v. Mingo Cnty. Bd. of Educ., 419 F. App'x 348, 353 (4th Cir. 2011) (per curiam), cert. denied, 132 S. Ct. 590 (2011) ("[T] he state's wish to prevent the spread of communicable diseases clearly constitutes a compelling interest.").

64. Michael H. Shapiro, Updating Constitutional Doctrine: An Extended Response to the Critique of Compulsory Vaccination, 12 YALE J. HEALTH POL'Y L. \& ETHICS 87, 122-37 (2012) (explaining the importance of the hepatitis B vaccine); Reiss \& Weithorn, supra note 13, at 7-8.

65. Muireann Brennan et al., Evidence for Transmission of Pertussis in Scbools, Massacbusetts, 1996: Epidemiologic Data Supported by Pulsed-Field Gel Electrophoresis Studies, 181 J. INFECTIOUS DISE.ASES 201, 214 (2000); Dieter Schenzle, An Age-Structured Model of Pre- and Post-Vaccination Measles Transmission, 1 IMA J. MATHEMATICS APPLIED MED. \&BIOLOGY 169 (1984).

66. See Feikin et al., supra note 38; Omer et al, supra note 39.

67. The one exception to the risk of infection is tetanus, also included in California's immunization requirements. Tetanus is not a transmittable disease. But as a practical matter, since the tetanus vaccine is bundled with other diseases and not available separately, it makes no difference. If children are required to be vaccinated against diphtheria and pertussis - both communicable- they will also get a tetanus vaccine. It's not an additional requirement. 
cinate their children and then use one of the untested, unsupported "detoxification" protocols suggested by antivaccine extremists. This process could be less than healthy for these children. Additionally, parents may decide to homeschool only out of concerns about vaccines, not out of desire, and maybe without being truly ready and able to do so. That would also not necessarily be in the child's best interest. ${ }^{68}$

These concerns hold, but they do not make SB 277 unconstitutional. Nor do they even make it a fundamentally flawed option: No law is perfect, and statutes often have to be compared with the status quo. SB 277 is better than the existing, easily obtained exemption that led some communities to have unacceptably high rates of exemptions, and offers many important benefits, making it worthy of support. ${ }^{69}$

In terms of constitutionality, the question is how narrowly the law should be tailored. If the goal is vaccination rates that are as high as possible, a policy with no exemptions is that which achieves the goal. ${ }^{70}$ The highest vaccination rates in our country are in Mississippi, one of the few states without a nonmedical exemption. ${ }^{71}$ And as mentioned above, higher vaccination rates mean fewer outbreaks. Mississippi has not had a case of measles in twenty years and had fifty-four cases of pertussis in 2014, with ten through August 8, 2015. ${ }^{72}$ By contrast, California, with its relatively easy to obtain PBE, had 136 cases of measles from the end of 2014 through April $2015 .{ }^{73}$ It had 11,203 cases of pertussis in

68. Dorit Rubinstein Reiss, Vacines, Measles, and Rights, 2 WAKE Forest L. REV. COMMON L. 138 (2015) (internal citations omitted), http://wakeforestlawreview.com/wpcontent/uploads/2015/03/Vaccines-Measles-and-Rights-by-Dorit-Rubinstein-ReissPDF1.pdf.

69. See Mello et al., supra note 57.

70. See Todd C. Frankel, Mississippi-Yes, Mississippi-Has the Nation's Best Cbild Vaccination Rate. Here's Why, WASH. POST (Jan. 30, 2015), http:/www.washingtonpost.com/ news/storyline/wp/2015/01/30/mississippi-yes-mississippi-has-the-nations-best-childvaccination-rate-heres-why [http://perma.cc/57TQ-PXAD] ("The secret of Mississippi's success stems from a strong public health program and-most importantly-a strict mandatory vaccination law that lacks the loopholes found in almost every other state."). West Virginia also has very, very low rates of exemptions. Ranee Seither et al., Morbidity and Mortality Weekly Report, CTRS. FOR DiseASE PREvEnTION \& CONTROL (Oct. 17, 2014), http://www.cdc.gov/mmwr/preview/mmwrhtml/mm6341a1.htm?s_cid=mm6341a1_e\#Tab2 [http://perma.cc/U7XT-MK5W].

71. Frankel, supra note 70.

72. Notifiable Diseases and Mortality Tables, 64 MORBIDITY \& MORTALITY WKLY. REP. ND-544, ND-482 (July 17, 2015), http://www.cdc.gov/mmwr/pdf/wk/mm6427md.pdf.

73. Immunization Branch, CAL. DeP'T Pub. Health, California Measles SURVEILLANCE UPDATE APRIL 17, 2015, at 1 (2015), https://www.cdph.ca.gov/ HealthInfo/discond/Documents/Measles_update_4-17-2015_public.pdf. 
2014 and 3404 by August 2015. ${ }^{74}$ Three infants died of pertussis in 2014 in California, and one has died as of June $2015 .{ }^{75}$ Even accounting for the difference in population size between the two states, these are stark differences.

Certainly, easy to obtain exemptions lead to lower vaccination rates, which increase the risk of outbreaks. Ideally, one would be able to mathematically predict the level of difficulty in obtaining vaccination exemptions that would effectively prevent outbreaks, but we do not have that information; right now, we are operating with uncertainty. How broad an exemption is justified in order to prevent a death? And should it really be the courts' job to second-guess the legislature's risk assessment in such a situation of uncertainty? My view is no. Since there are no good criteria to determine what is appropriately "narrow" in these circumstances-since it depends on the value put on a life-the democratically elected legislature should have leeway to reflect in its policy the state's values.

In addition, as discussed in Part IV, SB 277 does leave parents with options. As such, it is narrowly tailored to the goal of removing the risk that unvaccinated children pose to their classmates: Unvaccinated children cannot congregate in ways that undermine herd immunity and increase the risk of outbreaks, but they have access to several respectable educational opportunities that the state offers. And rather than forcing parents to vaccinate, the state is preserving their right to leave their children unvaccinated-but requiring them to act to reduce the risk that decision poses to others.

\section{WhOSE Right TOACCESS? SB 277 PROTECTS THE RIGHTOF ACCESS OF THOSEWHO CANNOT BEVACCINATED}

Senator Ben Allen, before the Senate Judiciary Committee, raised another powerful argument against attacks on SB 277's constitutionality. ${ }^{76}$ Senator Allen reminded the Committee what the result of easy-to-get PBEs is: schools with low vaccination rates. Such schools create real risks for children with medical contraindications, specifically those who cannot be vaccinated.

74. Cal. DeP'T Pub. Health, Pertussis Report August 3, 2015, at 2 tbl.1 (Aug. 3, 2015), http://www.cdph.ca.gov/programs/immunize/Documents/Pertussis\%20report\%208-3-2015.pdf. These numbers are drawn from California's Department of Health report, on the assumption that they are closest to the ground and have the best numbers on this issue.

75. Id. at 1

76. See Jenny Jiang, Transcript: CA Sen. Benjamin Allen's Opening Statement on SB 277 Before the Senate Judiciary Committee-April 28, 2015, WHAT THE FOLlY?! (Apr. 29, 2015), http://www.whatthefolly.com/2015/04/29/transcript-ca-sen-benjamin-allens-opening-statementon-sb-277-before-the-senate-judiciary-committee-april-28-2015 [http://perma.cc/7T7P-G6ZD]. 
For example, in the struggle over SB 277, the father of seven-year-old Rhett Krawitt, a leukemia survivor who remained unprotected from some diseases, talked about the parents' reluctance and hesitation to send Rhett to school before he could be vaccinated again given the high rate of exemptions. ${ }^{77}$ Rhett could not be vaccinated because of his cancer treatments and was very vulnerable to a preventable disease such as measles. In essence, easily obtained exemptions, by creating an environment more prone to outbreaks, make schools less safe for children such as Rhett - putting them directly at risk of preventable disease.

In that sense, an extremely loose exemption undermines access to school for those who cannot be vaccinated or for whom vaccines are not as effective for medical reasons. ${ }^{78}$ The parents of such children-cancer survivors, children with transplants, children allergic to vaccine components-do not have a choice. They cannot vaccinate their children, who often are especially vulnerable to the risk of infection. Low vaccination rates undermine these children's right to access education; limiting or removing exemptions improves it.

The state has to choose between the current system, which allows open access to schools to unvaccinated children, and providing safe access to children who cannot be vaccinated for medical reasons. Between these groups, it is the latter - the children with medical conditions that prevent vaccination-that is more similar to the groups California's constitution most clearly protects, those with immutable traits. The barrier to access is not of their making, and not one about which they have a choice. This is the group whose access should take priority and be granted special protection by the state and the courts.

Parents who choose not to vaccinate may be motivated by real fears about vaccines. But their fears tend to go against overwhelming scientific evidence. Protecting the access of those making counterevidentiary choices at the expense of access for those who do not actually have a choice is problematic.

77. See Tamar Lewin, Sick Cbild's Father Seeks Vaccination Requirement in California, N.Y. TIMES (Jan. 28, 2015), http://www.nytimes.com/2015/01/29/us/father-of-boy-with-leukemia-askscalifornia-school-officials-to-bar-unvaccinated-students.html [http://perma.cc/73LR-LTL7].

78. For example, in spring 2015 a woman taking medication that weakened her immune system died from measles pneumonia in Washington State. Press Release, Wash. State Dep't Health, Measles Led to Death of Clallam Co. Woman; First in US in a Dozen Years (Jul. 2, 2015), http://www.doh.wa.gov/Portals/1/Documents/1500/NewsReleases/2015/15-119-WA-

MeaslesRelatedDeath.pdf. 


\section{SB 277 DOES NOT REMOVECHOICE, THOUGHITLIMITSIT}

Opponents of SB 277 presented the legislation as removing parental choice and effectively forcing them to vaccinate. But SB 277 excludes from vaccination requirements a number of educational alternatives to public and private schooling. It does not require immunization of children schooled at home, even if their parents choose to conduct the homeschooling by filing as a private school. ${ }^{79}$ It also allows children to enroll in home-based independent study through their public school without being subject to immunization requirements. ${ }^{80}$

At the same time, SB 277 does condition attending private or public school on meeting immunization requirements, and in this, it imposes a limit on parental freedom: Parents can no longer send children to school unvaccinated. Is this removal of choice?

Consider for a moment why a parent may decide to homeschool. Several of the reasons mentioned on homeschooling associations' sites relate to family interactions and lifestyle. ${ }^{81}$ But other reasons include "[a]cademic excellence, physical safety" and fifty-five other safety issues that include bullying and gangs, or not being subject to the school curriculum or hours. ${ }^{82}$

Parents concerned about safety may feel they have no choice, and parents who oppose the school's curriculum may feel that it is being imposed on them. But the state is not required to increase guards at a school, or to change curricula to allow those parents to avoid homeschooling. Basically, the state sets requirements and provides conditions in school that the legislature or school administration concludes are adequate to protect children and allow an appropriate education, within budgetary constraints. There are constitutional limits on those choices, as Serrano demonstrates (and as addressed in Part I), but the state has substantial discretion in setting them. Parents who are sufficiently unhappy with state laws and regulations may choose to homeschool, and sometimes, they

79. S.B. 277, 2015-16 Leg., Reg. Sess. (Cal. 2015), ch. 35, 2015 Cal. Stat. 91, sec. 2, § 120335(f), http://www.leginfo.ca.gov/pub/15-16/bill/sen/sb_0251-0300/sb_277_bill_20150630_chaptered.pdf ("This section does not apply to a pupil in a home-based private school or a pupil who is enrolled in an independent study program pursuant to Article $5.5 \ldots$ and does not receive classroom-based instruction.").

80. Id.

81. See Frequently Asked Questions, CAL. HOMESCH. NETwORK, http://www.californiahomeschool.net /how-to-homeschool/faq [http://perma.cc/4PDR-XDG3] (last visited Sept. 28, 2015).

82. Lillian Jones, Considering Homescbooling: Introduction to Homescbooling, HOMESCHOOL Ass'N CAL., http://www.hsc.org/homeschoolinghelp/considering-homeschooling.html [https://web.archive.org/web/20150905122647/http://www.hsc.org/homeschoolinghelp/ considering-homeschooling.html] (last visited Sept. 28, 2015). 
will see the choice as constrained and as a choice between two evils. It is still, however, a choice.

The same is true regarding the choice to follow school immunization requirements. Parents do have a choice: They can vaccinate, protecting their children against disease, following the state requirements. Or, if sufficiently hostile to the requirement, they can choose one of the available options. There are several choices available. Parents can choose to homeschool as a private school, by filing an affidavit, ${ }^{83}$ alone or as part of a group of families (the statute was amended to allow a group of families to homeschool together). While hard for working parents, this decision can still be made feasible through the option of collaborating with other families. Or parents can hire an accredited tutor. ${ }^{84}$ Or parents can enroll their children in an independent study program offered by a public school.

These options may be inconvenient or challenging for some families. They may feel constrained and unhappy about the choice. They may correctly see it as limiting their child's educational opportunity. They may see it as a choice between evils, as unbearably hard. But they do have a choice. They can choose to protect their child from disease and send that child to school, or they can choose to take advantage of one of the other options offered by the state.

The state does not change its curriculum to accommodate parents so hostile to it that they would rather homeschool; the state does not have to avoid reasonable health regulations, such as vaccination requirements, to accommodate parents so frightened of vaccination (usually based on incorrect information) ${ }^{85}$ that they would rather homeschool. ${ }^{86}$

\section{CONCLUSION}

SB 277 generated substantial controversy. There can be legitimate debate on whether removing exemptions to school immunization requirements is appropriate from a policy standpoint, ${ }^{87}$ but opponents claiming that the bill is un-

83. CAL. EdUC. CODE $§ 33190$ (West 2009).

84. CAL. EDUC. CODE $§ 48224$ (West 2006).

85. See Paul A. Offit, DEADLY CHOICES 105-55 (2011); Reiss \& Weithorn, supra note 13, at Part IV (B).

86. It should be remembered that SB 277 does not remove medical exemptions. Children with valid medical reasons not to vaccinate are not required to vaccinate under the law. In fact, limiting exemptions to these children should lead to higher immunization rates, better herd immunity, and better protection for them.

87. Compare Daniel A. Salmon et al., Making Mandatory Vaccination Truly Compulsory: Well Intentioned but Ill Conceived, 15 LANCET INFECTIOUS DISEASES 872 (Aug. 2015), with Mello et al., supra note 57. 
constitutional are wrong. SB 277 does not infringe upon California's right to education and it also fits within our federal jurisprudence relating to vaccination requirements. In fact, it reinforces the right to education, by protecting schoolschoolchildren from disease, which is a precondition to receiving the education to which they are entitled. 
